\title{
The World Order in the Post-Coronavirus Era
}

Mehdi Sanaei

\author{
Mehdi Sanaei \\ University of Tehran, Iran \\ Department of International Relations \\ Senior Lecturer; \\ Head of the Center for Iranian and Eurasian Studies; \\ Senior Advisor to the Foreign Minister of Iran and former Ambassador of Iran to Russia \\ This article is an abridged version of the paper written for the Valdai Discussion Club. The \\ original version is available at: https://valdaiclub.com/a/highlights/world-order-in-post- \\ coronavirus-era/?sphrase_id $=662765$
}

DOI: $10.31278 / 1810-6374-2020-18-2-54-59$

As the international medical community speculates as to how long the coronavirus infection will last and what impact it will have on human health in general, the observers and scholars of international relations are puzzling over the consequences that world politics may face after this pandemic.

\section{THE ECONOMY: WHO WILL WIN?}

In the economic sphere, the answer is clear, to some extent. It is predicted that the size of national economies, especially in the countries which are most affected by the coronavirus, will decrease. The level of production and consumption, except for some hygiene products, will decline. Many small and large industries and businesses will go bankrupt inevitably, and the world's unemployment rate will skyrocket. A large number of big companies will have to revise the methods of production and distribution of their products. After the crisis, governments are also likely to use the principle of resilience, along with the principle of profitability, in the economy in critical situations. 


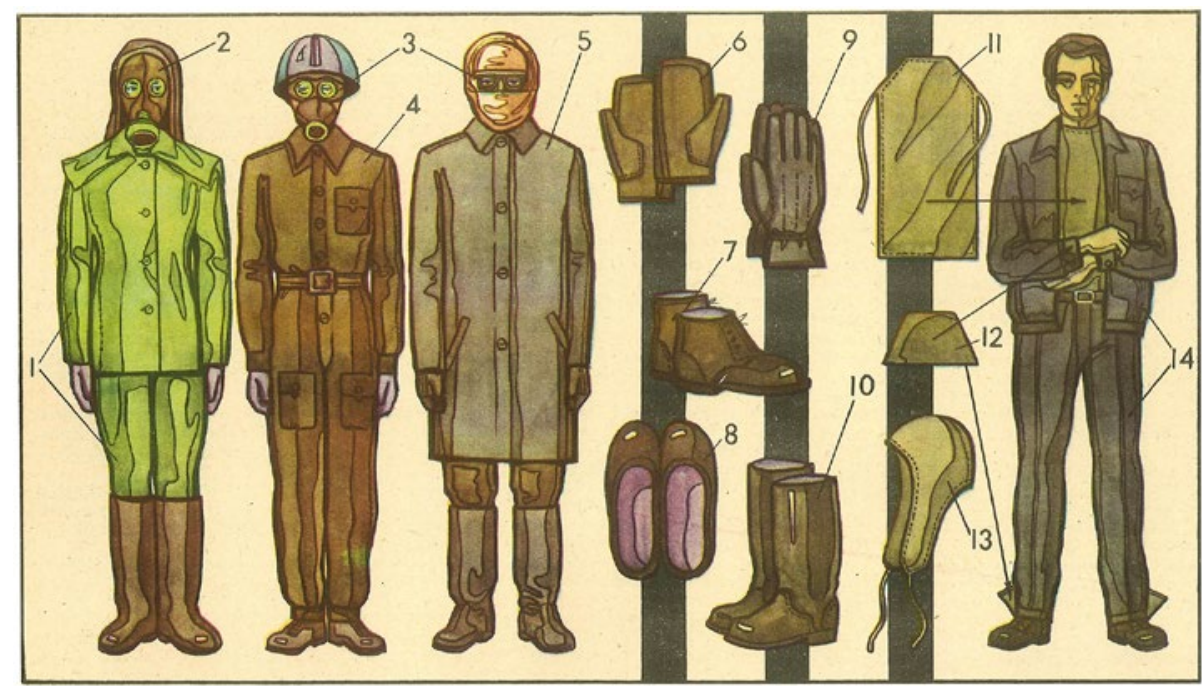

Online technology and industry have clearly emerged as the only winner in the coronavirus crisis. The online industry has managed to expand its legitimacy, compatibility and efficiency, and also has created some changes in the lifestyle of people in different areas.

\section{GOVERNMENTS, PEOPLE, ELITES}

There is a more difficult question to answer, though. What will the international order be like in the post-coronavirus era? Presumably, we are dealing with a multi-dimensional equation here.

In the coronavirus crisis, governments, nations, and elites have manifested themselves differently. Most national governments were at first shocked and then used the isolation approach. In dealing with the crisis, many of them chose the approach of competition and conflict, with some even resorting to accusations against other countries. In a surprising and unprecedented way, this caused the theft of masks and other medical products in airports and seaports, which exposed the inefficiency of the authorities in some countries. Meanwhile, powerful centralized governments enjoy high capabilities in decision-making and crisis management.

In the meantime, people who found themselves in a stressful situation due to their governments' decision to impose quarantine, with few 
exceptions, chose the path of peace and cooperation. The proof of this is the sense of unity among people, their benevolence towards each other, which we could observe on the balconies in Rome and also in Tehran, while maintaining the isolation regime. In different countries, we have witnessed altruism and self-sacrifice of the medical staff, and also amazing scenes of thanksgiving support to them from people.

As to world elites, the coronavirus aroused a mental storm among them, discussions of the need for a "global government," an "efficient international organization" or an "effective crisis resolution mechanism." On the one hand, this shows the growing awareness that, despite all the technological advances, humanity appears confused in the face of unknown crises. On the other hand, the fact that the current crisis is global but solutions to it are being sought at national and regional levels, makes the situation paradoxical and ambiguous for observers.

The necessity of fostering international cooperation is also proved by the fact that at present there is no effective international structure or mechanism. The inability of the United Nations to make any serious decision that would help settle the current crisis (and this was well seen in the controversy over the name of the virus and the UN Security Council's failure to approve the suspension of sanctions for the period of the coronavirus crisis) also underscores this necessity.

\section{REALISTS vS INTERNATIONALISTS}

So, what will the world be like after the coronavirus pandemic? International relations experts give different answers to this question, and their vision of the situation seems to change depending on what angle they take. The difference in opinions lies not only in the way they look at human nature and the nature of society, but also in their approaches to international politics. The specifics of the current situation and its paradoxical nature provide arguments for both realists and internationalists.

Scholars leaning towards realism point to the fact that the coronavirus attack has shown that however global the crisis is, it requires national solutions. They point to the fact that powerful countries are not helping weak ones and only strong governments that enjoy sufficient power can cope with the crisis quickly. The adherents of this approach conclude that 
the current crisis will lead to a breakdown of the global economy; it will strengthen nationalism, weaken globalization, and boost the importance of strong governments as was hailed by Jean Bodin and his followers.

In contrast to realists, internationalists maintain that the nationstate and the principle of national sovereignty are unable to solve global problems. Crises cannot be confined to national borders. Today, a single cough on one side of the globe can bring about catastrophic results on the other side. To prove that no country is capable of addressing global problems on its own, they point to Trumpism as an example. Trumpism, they claim, was doomed to failure from the very beginning. Economic and commercial neoliberalism, which has caused catastrophic danger to the environment and the planet on the whole, has shown that it does not have any remedy for curing the pains of human beings. In the face of an invisible demon named coronavirus, nuclear weapons and long-range missiles have proved useless.

In contrast, internationalists hope that multilateralism will eventually overcome unilateralism in the global arena, international cooperation will replace nationalism, and authoritarianism will leave the world scene. These thinkers are optimistic that the coronavirus crisis will make the world look for a more coordinated approach to solving complicated problems and preventing major catastrophes.

\section{WHAT'S NEXT?}

Notwithstanding the lack of transparency and the growing uncertainty about the dimensions and duration of the crisis, it is possible to make some predictions.

First, it is too early yet to talk about the establishment of a new international order because the crisis, despite the suffering it has brought to humanity, is not so terrible that a new building could be built on its ruins. Governments will ultimately cope with the difficulties caused by the pandemic, and competition will soon start among the manufacturers of COVID-19 vaccines and medicines.

The current trends will persist. The United Nations will continue weakening, and the United States' confrontation with China, and, to some extent, with Europe will increase. 
The world order has long been off the rails; this has become evident after the collapse of the bipolar order and the subsequent collapse of the American Dream, the brutal wars launched by the American coalition in the Middle East that claimed hundreds of thousands of innocent lives and made millions homeless, and the undermining of the principles of democracy and human rights for waging new wars and dropping bombs on the oppressed people. The current crisis will only exacerbate this situation.

Compared to similar events that have happened over the past 100 years, this crisis demonstrates an increase in people's awareness. This is mainly due to the extraordinary role of the media and the speed of information networks in the world. So, unlike before, the world is facing two realities at the same time: one is the crisis itself and the other one is the way it is perceived. In this situation the "structuralist approach" and attention to cultural identities become more important for examining the current state of the world and predicting future international developments.

The coronavirus crisis may bring closer various schools of international relations theory. All nations will have to consider more carefully such practices as "influence and power of sovereignty," "self-support" and "selfreliance of governments," in the way the realists see them. The crisis will convince the internationalists that establishing a global government or a full-fledged global mechanism, though necessary, is an early expectation, and that the nation-state will remain in the center of world politics. On the other hand, everyone will have to agree that full-fledged action and behavior of governments on the "conflict of interests" and "competition and conflict" principles do not meet the needs of nations and the current state of the world. As a result, one can expect the emergence of an updated version of realism or a new form of pragmatic internationalism.

Undoubtedly, in the post-coronavirus period the role of national governments and state institutions will be strengthened, and economic stability and investment in healthcare will take center stage. In the international arena, the failure of globalization processes will make nations seek a global mechanism to deal with crises and common threats. Multilateralism will strengthen its positions in world politics, and countries will move further away from U.S.-imposed globalization schemes. Due to the serious damage that this crisis is inflicting on people's faith in the United 
States and Europe, and the European Union's failure to help its memberstates, the image of the East will become more prominent in the eyes of the world. In these circumstances, countries such as China, Russia, India, and Iran will be able to be more active.

In recent weeks, some acclaimed international relations experts have made useful and interesting statements on the coronavirus crisis and the state of the international system. These statements have been reflected in Iran's domestic media. However, an article by well-known American politician and realist Henry Kissinger remarkably stands out among other publications. His stance should be viewed as a reaction to the United States' gradual loss of credibility as a global leader and its inability to manage the crisis as a nation-state. At the same time Kissinger has offered some recommendations for preventing the U.S.'s further decline.

The crisis will hit the hardest such economic sectors as energy, air transport, and tourism, while various areas of the cyber industry will reap benefits. However, we could also hope that cooperation of the cyber industry with other sectors, consolidation of some habits developed during the crisis, the change for a new lifestyle, the emergence of new consumption patterns due to the creation of new areas of economic activity, and new initiatives in the field of production, distribution and consumption will ultimately lead to economic prosperity in the post-coronavirus world. Naturally, the benefits for each country will depend on its capacity and talent.

Iran was one of the first countries to face the coronavirus outbreak, and despite the problems and damage caused by the epidemic, Tehran manages to control the crisis. In the international area, its government has voiced protest against the unfair, immoral and inhuman sanctions against Iran. Relying on the principle of regional cooperation Iran's foreign policy has been effectively contributing to resolving regional conflicts and helping neighboring countries settle their internal conflicts. With its diplomacy based on multilateralism, the Islamic Republic of Iran can employ its competence and potential for forming an international partnership to deter unilateralism and expand cooperation in Eurasia and Western Asia. 